\title{
How are Attitudes Toward COVID-19 Associated with Traveler Behavior During the Pandemic?
}

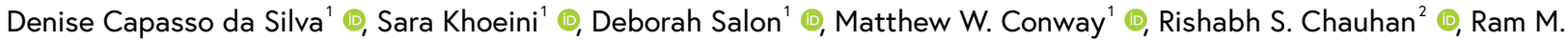

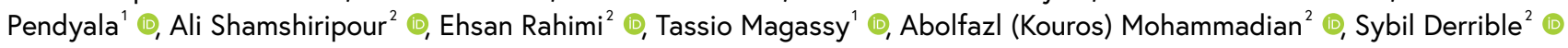 \\ ${ }^{1}$ Arizona State University, ${ }^{2}$ University of Illinois at Chicago \\ Keywords: covid-19, attitudes, traveler behavior \\ https://doi.org/10.32866/001c.24389
}

Findings

\begin{abstract}
This article uses data from the first wave of the COVID Future Panel study to evaluate attitudes towards COVID-19 and their influence on traveler behaviors. An exploratory factor analysis identified two underlying constructs based on the measured attitudes, namely "Concern about Pandemic Response" and "COVID Health Concern.” A cluster analysis based on the factor scores yielded four groups with distinct attitudes. Those primarily concerned about the pandemic response traveled the most using private vehicles, while those equally concerned about the response to the pandemic and the health effects of COVID-19 were found to use personal bicycles and transit the most.
\end{abstract}

\section{Questions}

This article investigates the relationship between attitudes toward COVID-19 and traveler behavior, particularly focusing on mode use and activity engagement during the pandemic. While attitudes toward COVID-19 have already been identified as affecting current and expected post-pandemic behaviors (Conway et al. 2020; Chauhan, Capasso da Silva, et al. 2021), this study explicitly distinguishes between and focuses on concerns about the response to the pandemic (as in a feeling that society is over-reacting and the economic impacts of shutting down are not justified) and health concerns about having a severe reaction to COVID.

The analysis in this article identified Concern about Pandemic Response and COVID Health Concern as two different attitudinal constructs. The research addresses how these COVID-19 attitudinal constructs are associated with traveler behaviors observed during the pandemic.

\section{Methods}

This study uses data from the first wave of the COVID Future Panel Survey (Salon et al. 2021; Chauhan, Conway, et al. 2021). The sample includes 7,593 respondents from across the United States (US) who completed the survey between June and October 2020 (Wave 1b). The data were weighted to replicate national distributions of age, education, gender, Hispanic status, household income, presence of children, and number of household vehicles. Importantly, the weighting methodology adjusted for the marginal distributions without inflating the sample size (for more information, please refer to Chauhan, Conway, et al. 2021). 


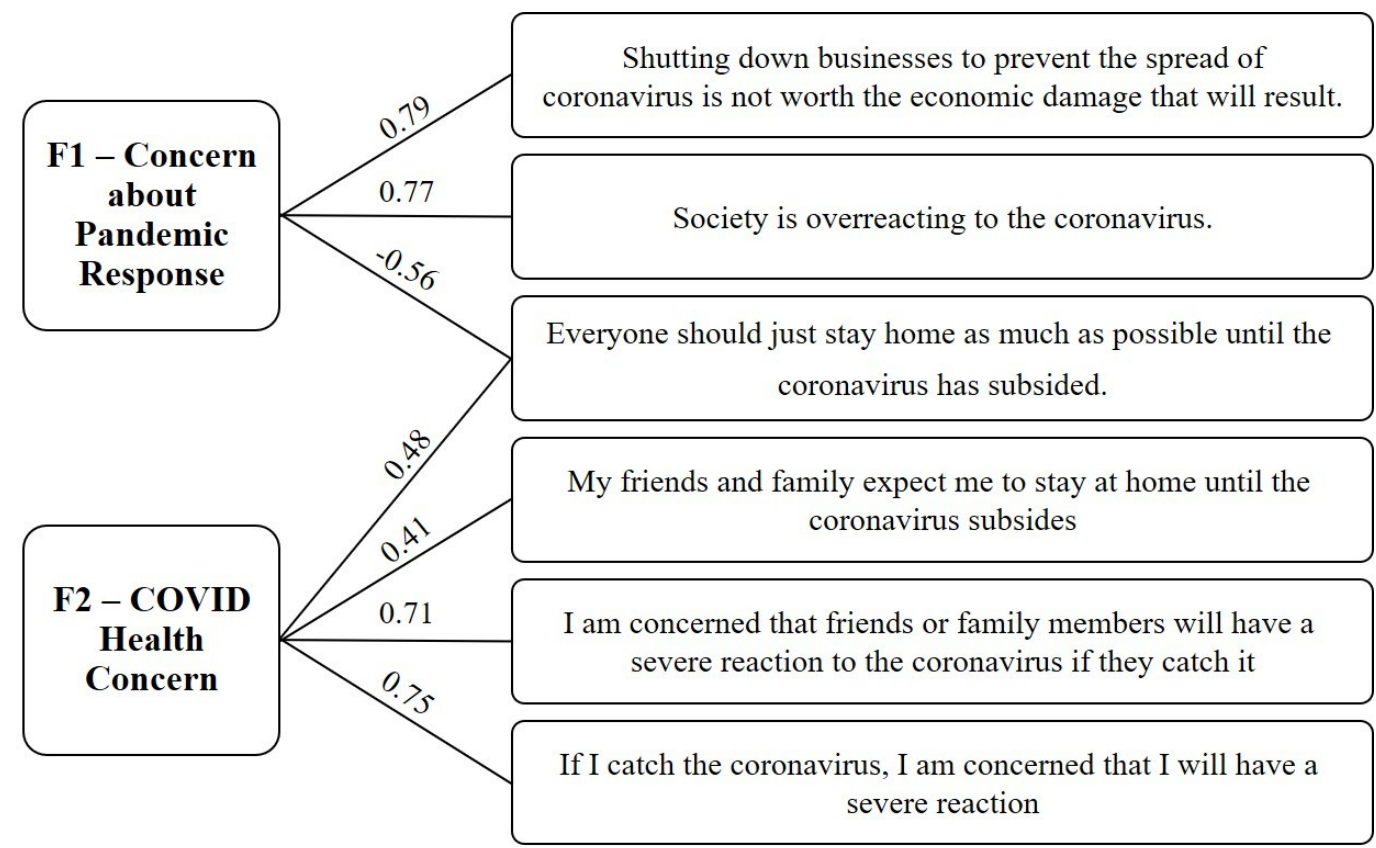

Note: Only loadings greater in magnitude than 0.4 are shown in the figure.

Figure 1. Factor Loadings from Exploratory Factor Analysis (Minimum Residual Method with Varimax Rotation)

Attitudes toward COVID-19 were measured using six agree/disagree statements (Figure 1) on a 5-point Likert scale (Strongly disagree, Disagree, Neutral, Agree, Strongly agree). To extract attitudinal constructs based on these statements, an Exploratory Factor Analysis (EFA) was performed and factor scores were extracted using the fitted model through the FactorAnalyzer Python package (Biggs 2019). The two identified constructs (Figure 1) are Concern about Pandemic Response and COVID Health Concern. The selected solution explains $55.4 \%$ of the variance observed on the selected original statements.

Based on the computed factor scores for each individual in the sample, a nonparametric K-means cluster analysis was performed. The clustering identified four groups of respondents; the grouping was found to be both intuitive and statistically robust. Respondents were grouped based on their concern about having a severe reaction to the virus and their concern about societal response to the pandemic and its economic impacts. The four identified attitudinal clusters are: (1) Primarily concerned about health, (2) Equally concerned about health and the societal response, (3) Least concerned about health and about the response, and (4) Primarily concerned about the response. Figure 2 shows how cluster membership relates to the factor scores, as well as the weighted sample of the four attitudinal clusters. About two-thirds of the sample fall into clusters reflecting strong concerns about the health effects of COVID. As two normalized factor scores are used in the cluster analysis, the cluster analysis roughly divided the sample into quadrants (Figure 2). While the group primarily concerned with the health effects is the largest share of the sample, 


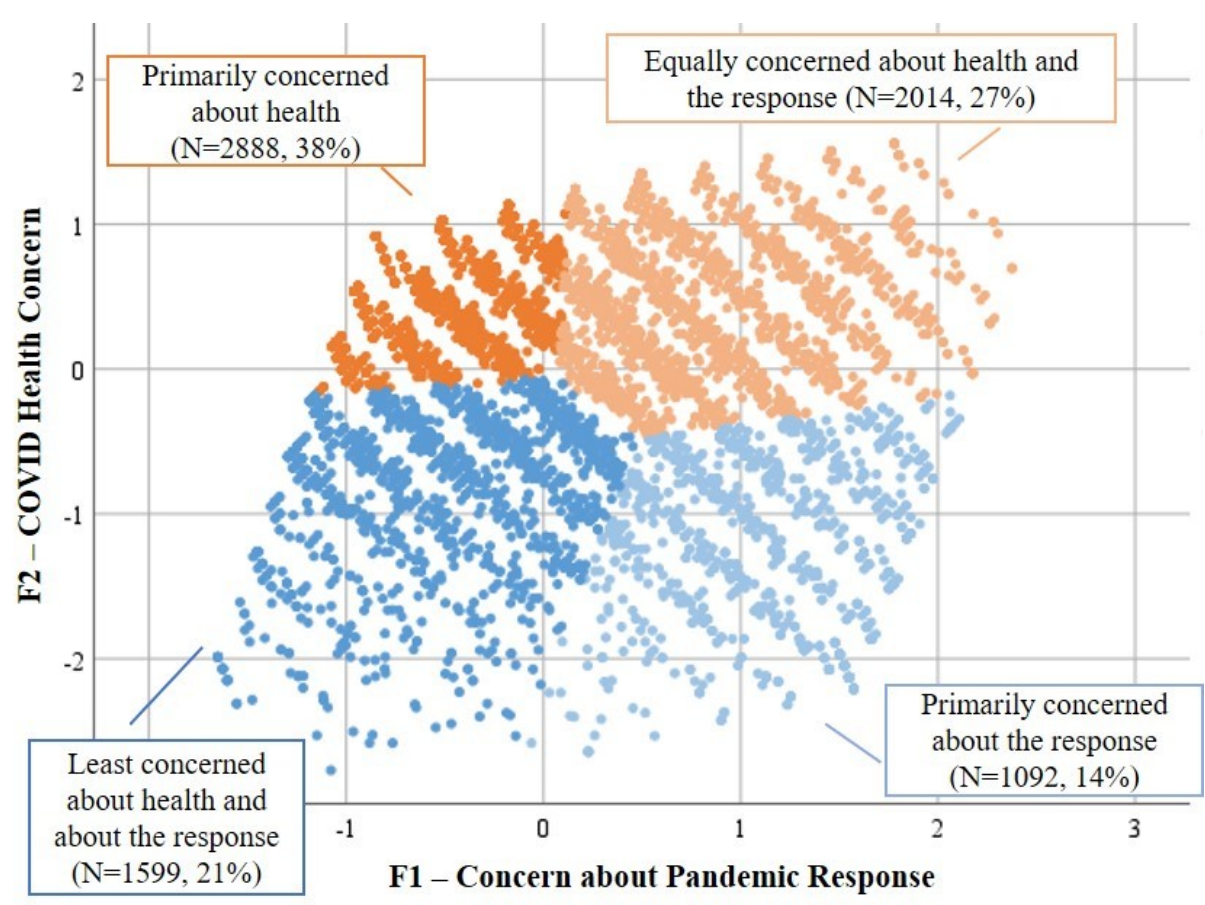

Figure 2. Cluster Membership by Factor Score and Weighted Sample of Each Cluster

it represents the smallest area of Figure 2; this result indicates that the respondents in this group are more similar to one another than the respondents within the other clusters.

To better understand the difference among the four clusters, chi-square analyses were performed on the weighted frequencies of the distributions shown in Tables 1 and 2 ; for binary characteristics, such as presence of children and if a mode was used or not, while only one category is shown in the tables, the full distribution was used to compute chi-square test statistics. The chisquare analysis revealed that all differences reported on this paper are statistically significant at a 5 percent significance level. Standard errors for the proportions shown in this paper are presented in the appendix; all calculated sample standard errors are below 2.5 percentage points, with the exception of percent of workers working entirely from home, for the group who is primarily concerned about the response.

In addition to conducting a descriptive analysis of the identified clusters, ordered probit models were estimated to investigate the multivariate relationships between COVID-related attitudes and traveler behaviors during the pandemic. The explored response variables are frequency of private vehicle use, transit use, in-person grocery shopping, restaurant patronage, and work from home (for workers who could). In addition to the identified factors, the models control for COVID risk perception, person and household socioeconomic characteristics, location, pre-pandemic behavior (considered exogenous in this study), and other attitudes. While the authors acknowledge the endogeneity issue that arises from including pre-pandemic behaviors as 


\begin{tabular}{|c|c|c|c|c|c|}
\hline & & $\begin{array}{c}\text { Primarily } \\
\text { concerned } \\
\text { about health }\end{array}$ & $\begin{array}{l}\text { Equally } \\
\text { concerned } \\
\text { about health } \\
\text { and the } \\
\text { response } \\
\end{array}$ & $\begin{array}{l}\text { Least } \\
\text { concerned } \\
\text { about health } \\
\text { and about } \\
\text { the response }\end{array}$ & $\begin{array}{l}\text { Primarily } \\
\text { concerned } \\
\text { about the } \\
\text { response }\end{array}$ \\
\hline & Weighted sample: & 2884 & 2014 & 1599 & 1092 \\
\hline \multirow{5}{*}{$\begin{array}{l}\text { Age } \\
\left(\chi^{2}=128.0, p=0.000\right)\end{array}$} & $18-29$ years & $18 \%$ & $22 \%$ & $28 \%$ & $19 \%$ \\
\hline & $30-44$ years & $23 \%$ & $27 \%$ & $25 \%$ & $28 \%$ \\
\hline & $45-59$ years & $25 \%$ & $25 \%$ & $21 \%$ & $29 \%$ \\
\hline & $60+$ years & $34 \%$ & $26 \%$ & $26 \%$ & $24 \%$ \\
\hline & Average age & $\begin{array}{c}49.0 \\
(\mathrm{~s}=17.9)\end{array}$ & $\begin{array}{c}46.3 \\
(\mathrm{~s}=17.8)\end{array}$ & $\begin{array}{c}43.9 \\
(\mathrm{~s}=17.8)\end{array}$ & $\begin{array}{c}46.5 \\
(\mathrm{~s}=16.1) \\
\end{array}$ \\
\hline \multirow{2}{*}{$\begin{array}{l}\text { Gender } \\
\left(\chi^{2}=78.4, p=0.000\right)\end{array}$} & Female & $56 \%$ & $46 \%$ & $54 \%$ & $44 \%$ \\
\hline & Male & $44 \%$ & $54 \%$ & $46 \%$ & $56 \%$ \\
\hline \multirow{3}{*}{$\begin{array}{l}\text { Education } \\
\left(\chi^{2}=50.9, p=0.000\right)\end{array}$} & High school or less & $35 \%$ & $42 \%$ & $42 \%$ & $42 \%$ \\
\hline & Some college & $33 \%$ & $27 \%$ & $30 \%$ & $32 \%$ \\
\hline & Bachelor or higher & $32 \%$ & $31 \%$ & $28 \%$ & $26 \%$ \\
\hline \multirow{7}{*}{$\begin{array}{l}\text { Annual household } \\
\text { income in } 2019 \text { (i.e., } \\
\text { pre-pandemic } \\
\text { income) } \\
\left(\chi^{2}=19.9, p=0.003\right)\end{array}$} & Less than $\$ 35,000$ & $20 \%$ & $21 \%$ & $24 \%$ & $18 \%$ \\
\hline & $\$ 35,000$ to $\$ 49,999$ & $12 \%$ & $14 \%$ & $13 \%$ & $10 \%$ \\
\hline & $\$ 50,000$ to $\$ 74,999$ & $18 \%$ & $16 \%$ & $17 \%$ & $19 \%$ \\
\hline & $\$ 75,000$ to $\$ 99,999$ & $13 \%$ & $10 \%$ & $11 \%$ & $14 \%$ \\
\hline & $\$ 100,000$ to $\$ 124,999$ & $14 \%$ & $13 \%$ & $14 \%$ & $17 \%$ \\
\hline & $\$ 125,000$ or more & $23 \%$ & $26 \%$ & $21 \%$ & $22 \%$ \\
\hline & $\begin{array}{l}\text { Share below the poverty level* } \\
\left(\chi^{2}=25.8, p=0.000\right)\end{array}$ & $11 \%$ & $16 \%$ & $15 \%$ & $10 \%$ \\
\hline \multirow{5}{*}{$\begin{array}{l}\text { Household vehicles } \\
\left(\chi^{2}=142.4, p=0.000\right)\end{array}$} & 0 & $9 \%$ & $8 \%$ & $14 \%$ & $5 \%$ \\
\hline & 1 & $22 \%$ & $26 \%$ & $23 \%$ & $19 \%$ \\
\hline & 2 & $40 \%$ & $37 \%$ & $35 \%$ & $37 \%$ \\
\hline & 3 & $22 \%$ & $18 \%$ & $21 \%$ & $27 \%$ \\
\hline & 4 or more & $7 \%$ & $11 \%$ & $7 \%$ & $12 \%$ \\
\hline $\begin{array}{l}\text { Presence of children } \\
\left(\chi^{2}=60.5, p=0.000\right)\end{array}$ & Present & $33 \%$ & $41 \%$ & $31 \%$ & $42 \%$ \\
\hline \multirow{5}{*}{$\begin{array}{l}\text { Attitudes (Percent of } \\
\text { those who agree or } \\
\text { strongly agree with } \\
\text { statement) }\end{array}$} & $\begin{array}{l}\text { Learning how to use new } \\
\text { technologies is often frustrating } \\
\text { to me }\left(\chi^{2}=92.2, p=0.000\right)\end{array}$ & $37 \%$ & $45 \%$ & $30 \%$ & $34 \%$ \\
\hline & $\begin{array}{l}\text { I am committed to using less } \\
\text { polluting means of transportation } \\
\text { as much as possible }\left(\chi^{2}=298.1,\right. \\
p=0.000)\end{array}$ & $52 \%$ & $46 \%$ & $42 \%$ & $22 \%$ \\
\hline & $\begin{array}{l}\text { Even if I do not end up buying } \\
\text { anything, I still enjoy going to } \\
\text { stores and browsing }\left(\chi^{2}=40.0 \text {, }\right. \\
p=0.000)\end{array}$ & $56 \%$ & $65 \%$ & $58 \%$ & $61 \%$ \\
\hline & $\begin{array}{l}\text { Having shops and services within } \\
\text { walking distance of my home is } \\
\text { important to me }\left(\chi^{2}=76.3 \text {, }\right. \\
p=0.000)\end{array}$ & $62 \%$ & $58 \%$ & $58 \%$ & $46 \%$ \\
\hline & $\begin{array}{l}\text { I dislike change }\left(\chi^{2}=53.0\right. \\
p=0.000)\end{array}$ & $42 \%$ & $47 \%$ & $36 \%$ & $44 \%$ \\
\hline
\end{tabular}

Table 1. Demographic Characteristics of Attitudinal Clusters (Weighted)

* Approximate poverty level by household size, based on values established by the United States Census Bureau (2021). Approximate thresholds considered based on the income categories provided in the survey are $\$ 15,000$ for households size 1 or 2; $\$ 25,000$ for households size 3 or $4 ; \$ 35,000$ for households with 5 to 7 people; and $\$ 50,000$ for households with 8 people or more. 


\begin{tabular}{|c|c|c|c|c|c|c|}
\hline & & & $\begin{array}{c}\text { Primarily } \\
\text { concerned } \\
\text { about health }\end{array}$ & $\begin{array}{c}\text { Equally } \\
\text { concerned } \\
\text { about health } \\
\text { and the } \\
\text { response } \\
\end{array}$ & $\begin{array}{l}\text { Least } \\
\text { concerned } \\
\text { about health } \\
\text { and about } \\
\text { the response }\end{array}$ & $\begin{array}{c}\text { Primarily } \\
\text { concerned } \\
\text { about the } \\
\text { response }\end{array}$ \\
\hline \multicolumn{3}{|c|}{ Weighted sample: } & 2884 & 2014 & 1599 & 1092 \\
\hline \multirow{4}{*}{$\begin{array}{l}\text { Restaurant Patronage } \\
\text { Number of days dining } \\
\text { out in the past week } \\
\left(\chi^{2}=482.2, p=0.000\right)\end{array}$} & 0 & & $81 \%$ & $60 \%$ & $71 \%$ & $53 \%$ \\
\hline & 1 & & $14 \%$ & $23 \%$ & $19 \%$ & $30 \%$ \\
\hline & $2-3$ & & $4 \%$ & $13 \%$ & $10 \%$ & $15 \%$ \\
\hline & 4 or more & & $1 \%$ & $4 \%$ & $1 \%$ & $2 \%$ \\
\hline \multirow{4}{*}{$\begin{array}{l}\text { In-person Grocery } \\
\text { Shopping Number of } \\
\text { days grocery shopping } \\
\text { in the past week } \\
\left(\chi^{2}=207.7, p=0.000\right)\end{array}$} & 0 & & $25 \%$ & $16 \%$ & $17 \%$ & $12 \%$ \\
\hline & 1 & & $47 \%$ & $44 \%$ & $46 \%$ & $43 \%$ \\
\hline & $2-3$ & & $26 \%$ & $33 \%$ & $34 \%$ & $38 \%$ \\
\hline & 4 or more & & $3 \%$ & $7 \%$ & $4 \%$ & $7 \%$ \\
\hline \multirow{4}{*}{$\begin{array}{l}\text { Online Shopping } \\
\text { Number of days } \\
\text { ordering non-grocery } \\
\text { items in the past week } \\
\left(\chi^{2}=98.9, p=0.000\right)\end{array}$} & 0 & & $34 \%$ & $35 \%$ & $42 \%$ & $44 \%$ \\
\hline & 1 & & $27 \%$ & $26 \%$ & $29 \%$ & $30 \%$ \\
\hline & $2-3$ & & $30 \%$ & $30 \%$ & $23 \%$ & $21 \%$ \\
\hline & 4 or more & & $9 \%$ & $9 \%$ & $6 \%$ & $6 \%$ \\
\hline \multirow{3}{*}{$\begin{array}{l}\text { Work from Home } \\
\text { (Workers who had the } \\
\text { choice to work from } \\
\text { home) }\end{array}$} & \multicolumn{2}{|c|}{ Weighted sample size } & 780 & 614 & 430 & 261 \\
\hline & \multicolumn{2}{|c|}{$\begin{array}{c}\text { Percent Working Entirely } \\
\text { Remote in Past } 7 \text { Days } \\
\text { Zero trips to work, worked from } \\
\text { home } 5+\text { days }\left(\chi^{2}=118.2, p=0.000\right)\end{array}$} & $58 \%$ & $30 \%$ & $56 \%$ & $44 \%$ \\
\hline & \multicolumn{2}{|c|}{$\begin{array}{l}\text { Average days working from } \\
\text { home during the past week }\end{array}$} & $\begin{array}{c}4.8 \\
(\mathrm{~s}=1.8)\end{array}$ & $\begin{array}{c}4.3 \\
(\mathrm{~s}=1.8)\end{array}$ & $\begin{array}{c}4.6 \\
(\mathrm{~s}=2.0)\end{array}$ & $\begin{array}{c}4.2 \\
(\mathrm{~s}=2.1)\end{array}$ \\
\hline \multirow{7}{*}{$\begin{array}{l}\text { Daily travel } \\
\text { (Based on the number of } \\
\text { days mode was used in } \\
\text { the 7-day period prior } \\
\text { to the survey) }\end{array}$} & \multirow{4}{*}{$\begin{array}{l}\text { Private vehicle Number } \\
\text { of days using the mode } \\
\text { in the past week } \\
\left(\chi^{2}=376, p=0.000\right)\end{array}$} & $0-1$ & $24 \%$ & $20 \%$ & $27 \%$ & $12 \%$ \\
\hline & & $2-3$ & $27 \%$ & $27 \%$ & $22 \%$ & $13 \%$ \\
\hline & & $4-6$ & $27 \%$ & $27 \%$ & $23 \%$ & $25 \%$ \\
\hline & & 7 & $22 \%$ & $26 \%$ & $28 \%$ & $50 \%$ \\
\hline & \multicolumn{2}{|c|}{$\begin{array}{l}\text { Transit use Share of respondents } \\
\text { who used the mode }\left(\chi^{2}=77.1\right. \\
\qquad=0.000)\end{array}$} & $7 \%$ & $15 \%$ & $9 \%$ & $8 \%$ \\
\hline & \multicolumn{2}{|c|}{$\begin{array}{l}\text { Personal bike Share of } \\
\text { respondents who used the mode } \\
\left(\chi^{2}=99.6, p=0.000\right)\end{array}$} & $20 \%$ & $30 \%$ & $19 \%$ & $18 \%$ \\
\hline & \multicolumn{2}{|c|}{$\begin{array}{l}\text { Immobility Share of respondents } \\
\text { who did not travel at all }\left(\chi^{2}=24.1 \text {, }\right. \\
\qquad p=0.000)\end{array}$} & $4 \%$ & $3 \%$ & $3 \%$ & $2 \%$ \\
\hline
\end{tabular}

Table 2. Pandemic-era Behavioral Characteristics of Different Attitudinal Clusters (Weighted)

explanatory variables for explaining during-pandemic behavior, not including those variables would cause an omitted variable bias and ignore the presence of state dependence in behaviors.

\section{Findings}

A key finding of this research is the identification and characterization of groups of people who perceive the pandemic in different ways (Table 1). Comparing across groups in each row allows for understanding how different market segments feel about the pandemic. The largest differences are seen 
among different household structures, genders, and attitudinal groups. A higher proportion of the respondents in groups primarily concerned about societal response reported having children; school closures might have played a role in those perceptions. Similarly, respondents concerned about health are more often female, and respondents concerned about the response are more often male. Those least concerned about health and the response indicated greater tech-savviness and openness to change. In contrast, the strongest preference towards using less-polluting means of transportation and towards mixed-use neighborhoods was observed among those concerned the most about the health effects of COVID.

As expected, those with different perceptions about COVID-19 reported distinct behaviors during the pandemic (Table 2). In particular, there were significant differences in restaurant patronage between attitudinal clusters. Those who are concerned about a societal over-reaction to the virus ate out more often than those who believe in staying at home regardless of the economic impact. Among those able to work from home, respondents concerned primarily about health telecommuted, on average, $14 \%$ more than respondents concerned only about societal response. An examination of mode use patterns shows that those concerned primarily about the response reported using private vehicles close to $40 \%$ more often than the other groups. Those who are equally concerned about getting sick and about the societal response reported using transit more than other groups by a factor of almost two. Consistent with the notion that the relationship between attitudes and behavior is bidirectional (Kroesen, Handy, and Chorus 2017), the fear of exposure to the virus while riding transit may be impacting their level of concern. This same group reported bicycling about $50 \%$ more than other groups as well.

Table 3 shows the results of the set of ordered probit models that investigate the multivariate relationships driving behaviors during the pandemic, in the context of one's attitudes. After controlling for respondents' personal and household characteristics, location, pre-pandemic behaviors, and other general attitudes, COVID-related attitudinal factors were still statistically significant in models of traveler behavior and activity engagement during the pandemic. Concern about pandemic response and feeling that society might be overreacting to the virus is related to increased frequency of dining out and private vehicle use. Concern about having a severe reaction to the virus is related to increased telecommuting and decreased in-person grocery shopping and restaurant dining. Highlighting the effect of COVID perceptions on traveler behaviors during the pandemic, the models in Table 3 show that perceiving an activity as high or extremely high risk (of being exposed to COVID) decreased its frequency. Moreover, in all five models, pre-pandemic behavior is a strong and significant predictor of pandemic-era behavior, indicating considerable presence of state-dependence in traveler behaviors. 
Table 3. Ordered Probit Models of the Relationship Between Attitudes and Travel Behavior During the Pandemic

Number of days using mode/doing activity

Private vehicle

Frequency categories

0-1

$2-3$
$4-6$

7

Estimate

(t-stat)

$0.15(10.48)$

Factor 1: Concern about pandemic response

Factor 2: COVID health concern

COVID Attitudes

COVID risk: Riding transit is risky

COVID risk: Grocery shop in person is risky

COVID risk: Going to work is risky

Private vehicle use - Never

Private vehicle use - Every day

Transit use - Weekly

Shop for grocery - A few times/month

Pre-pandemic

Behavior

Person

Characteristics

$-0.13(-8.58)$
Shop for grocery - A few times/week

Shop for grocery - Every day

Dine out - A few times/month

Dine out - A few times/week

Dine out - Every day

Work from home - At least once/week

Work from home - Had option, but never did

Age: $30-44$

Age: $45-59$

Age: 60 plus

Education: Some college

Education: Bachelor's or higher

Gender: Female

Race: Black or African American

Race: Asian

Hispanic

Disability: Reported at least one disability (vision,physical,hearing,cognitive)

Employed during the time of the survey

Industry: Essential workers

Industry: Manufacturing and construction

Tested positive for the virus

Transit

Grocery

Shopping

Dining Out

Working from home

0

1-2

1-2

$5+$

$2+$

$2+$

Estimate

(t-stat)

(t-stat)

Estimate

(t-stat)

Estimate

(t-stat)

$-0.13(-4.03)$

0.18 (11.66)

0.31 (17.79)

0.04 (1.08)

\begin{tabular}{|c|c|c|c|c|}
\hline & $-0.44(-7.1)$ & & & \\
\hline & & $-0.23(-7.24)$ & & \\
\hline & & & & $0.26(4.21)$ \\
\hline \multicolumn{5}{|l|}{$-0.88(-12.12)$} \\
\hline \multicolumn{5}{|l|}{$0.92(30.51)$} \\
\hline & $1.18(17.88)$ & & & \\
\hline & & $0.69(9.28)$ & & \\
\hline & & 1.27 (17.18) & & \\
\hline & & $1.84(17.67)$ & & \\
\hline & & & $0.61(12.08)$ & \\
\hline & & & $1.11(20.7)$ & \\
\hline & & & 1.75 (14.21) & \\
\hline & & & & $0.37(5.91)$ \\
\hline & & & & $-0.41(-3.7)$ \\
\hline & $0.16(2.6)$ & & $-0.18(-3.63)$ & \\
\hline & & & $-0.3(-5.83)$ & $0.12(1.83)$ \\
\hline & $-0.41(-5.14)$ & & $-0.24(-4.72)$ & \\
\hline$-0.1(-2.62)$ & & $-0.13(-3.29)$ & $-0.1(-2.21)$ & \\
\hline$-0.23(-5.97)$ & & $-0.19(-4.56)$ & $-0.12(-2.58)$ & $0.15(2.28)$ \\
\hline$-0.08(-2.95)$ & $-0.39(-6.83)$ & $-0.14(-4.98)$ & $-0.1(-2.9)$ & $0.18(3.06)$ \\
\hline & $0.4(5.53)$ & $0.32(6.99)$ & & $0.21(2.28)$ \\
\hline$-0.23(-3.8)$ & & $0.13(2.16)$ & $-0.24(-3.1)$ & \\
\hline & & $0.16(3.46)$ & & \\
\hline$-0.09(-2.65)$ & $0.34(5.5)$ & & $0.16(4.04)$ & \\
\hline $0.24(8.48)$ & $0.3(4.61)$ & $0.13(4.51)$ & $0.15(4.11)$ & \\
\hline & & & & $-0.32(-5.38)$ \\
\hline & & & & $-0.42(-3.24)$ \\
\hline$-0.32(-2.91)$ & $0.56(3.25)$ & & $0.29(2.29)$ & \\
\hline
\end{tabular}

$09(-5.64)$

$-0.13(-7.27)$

\begin{tabular}{|c|c|c|c|c|}
\hline & & $-0.23(-7.24)$ & & \\
\hline & & & & $0.26(4.21)$ \\
\hline \multicolumn{5}{|l|}{$-0.88(-12.12)$} \\
\hline \multicolumn{5}{|l|}{$0.92(30.51)$} \\
\hline & $1.18(17.88)$ & & & \\
\hline & & $0.69(9.28)$ & & \\
\hline & & $1.27(17.18)$ & & \\
\hline & & $1.84(17.67)$ & & \\
\hline & & & $0.61(12.08)$ & \\
\hline & & & $1.11(20.7)$ & \\
\hline & & & 1.75 (14.21) & \\
\hline & & & & $0.37(5.91)$ \\
\hline & & & & $-0.41(-3.7)$ \\
\hline & $0.16(2.6)$ & & $-0.18(-3.63)$ & \\
\hline & & & $-0.3(-5.83)$ & $0.12(1.83)$ \\
\hline & $-0.41(-5.14)$ & & $-0.24(-4.72)$ & \\
\hline$-0.1(-2.62)$ & & $-0.13(-3.29)$ & $-0.1(-2.21)$ & \\
\hline$-0.23(-5.97)$ & & $-0.19(-4.56)$ & $-0.12(-2.58)$ & $0.15(2.28)$ \\
\hline$-0.08(-2.95)$ & $-0.39(-6.83)$ & $-0.14(-4.98)$ & $-0.1(-2.9)$ & $0.18(3.06)$ \\
\hline & $0.4(5.53)$ & $0.32(6.99)$ & & $0.21(2.28)$ \\
\hline$-0.23(-3.8)$ & & $0.13(2.16)$ & $-0.24(-3.1)$ & \\
\hline & & $0.16(3.46)$ & & \\
\hline$-0.09(-2.65)$ & $0.34(5.5)$ & & $0.16(4.04)$ & \\
\hline $0.24(8.48)$ & $0.3(4.61)$ & $0.13(4.51)$ & $0.15(4.11)$ & \\
\hline & & & & $-0.32(-5.38)$ \\
\hline & & & & $-0.42(-3.24)$ \\
\hline$-0.32(-2.91)$ & $0.56(3.25)$ & & $0.29(2.29)$ & \\
\hline
\end{tabular}




\begin{tabular}{|c|c|c|c|c|c|c|}
\hline \multirow{7}{*}{ Household } & Children present in the household & & & $-0.04(-1.41)$ & & \\
\hline & Household vehicles: 0 & & $-0.68(-8.22)$ & & & \\
\hline & Household vehicles: 1 or more & $1.23(15.2)$ & & & & \\
\hline & Household vehicles: 3 or more & & & & $0.19(4.73)$ & \\
\hline & Income: $\$ 35,000$ to $\$ 99,999$ & & $-0.41(-6)$ & $-0.12(-3.23)$ & & \\
\hline & Income: $\$ 100,000$ or more & & $-0.68(-7.98)$ & $-0.19(-4.48)$ & & $0.23(3.96)$ \\
\hline & Income decreased during the pandemic & & $-0.2(-3.34)$ & $-0.08(-2.77)$ & $-0.13(-3.85)$ & $-0.15(-2.61)$ \\
\hline \multirow{5}{*}{ Location } & Census division: East North Central (IN,IL,MI,OH,WI) & $0.1(2.77)$ & & & & \\
\hline & Census division: Mountain except Arizona (CO,ID,NM,MT,UT,NV,WY) & & & & $0.16(3.28)$ & \\
\hline & Census division: South Central (AL,KY,MS,TN,AR,LA,OK,TX) & & & & & $0.18(1.96)$ \\
\hline & Population density: Rural & $0.16(2.94)$ & $-0.77(-5.1)$ & & & \\
\hline & Population density: Suburban & $0.1(3.21)$ & $-0.37(-6.34)$ & & & \\
\hline \multirow{10}{*}{ Other Attitudes } & Agree: I liked being outside. & $0.13(3.15)$ & & & & \\
\hline & Agree: Learning how to use new technologies is often frustrating. & & $0.26(4.3)$ & $0.16(5.42)$ & $0.14(4.15)$ & $-0.22(-3.7)$ \\
\hline & Agree: I dislike change. & & $-0.14(-2.43)$ & & & \\
\hline & $\begin{array}{l}\text { Agree: I am committed to using a less polluting means of transportation as much as } \\
\text { possible. }\end{array}$ & & $0.4(6.82)$ & & & \\
\hline & Agree: Having shops and services within walking distance of my home is important. & & & $0.11(3.93)$ & & \\
\hline & Agree: In-person shopping is usually a chore for me. & & & $-0.13(-4.64)$ & & \\
\hline & Agree: I like working from home. & & & & & $0.52(7.9)$ \\
\hline & Sample size (unweighted) & 7047 & 7012 & 7034 & 7041 & 2116 \\
\hline & Pseudo R-Square & 0.154 & 0.376 & 0.089 & 0.121 & 0.082 \\
\hline & Thresholds: Estimate (t-stat) & $\begin{array}{c}0 \mid 1 \\
0.72(7.64) \\
1 \mid 2 \\
1.7(17.81) \\
2 \mid 3 \\
2.59(26.83)\end{array}$ & $\begin{array}{c}0 \mid 1 \\
0.48(4.10)\end{array}$ & $\begin{array}{c}0 \mid 1 \\
-0.17(-1.93) \\
1 \mid 2 \\
1.25(14.37)\end{array}$ & $\begin{array}{c}0 \mid 1 \\
1.10(15.22) \\
1 \mid 2 \\
1.89(25.41)\end{array}$ & $\begin{array}{c}0 \mid 1 \\
-1.16(-11.44) \\
1 \mid 2 \\
-0.33(-3.45) \\
2 \mid 3 \\
0.31(3.23)\end{array}$ \\
\hline
\end{tabular}




\section{Acknowledgments}

This research was financially supported by the National Science Foundation (NSF) RAPID program under grants no. 2030156 and 2029962, the Center for Teaching Old Models New Tricks (TOMNET), the Knowledge Exchange for Resilience at Arizona State University, the NSF-funded Social Science Extreme Events Research (SSEER) network, and the CONVERGE facility at the Natural Hazards Center at the University of Colorado Boulder.

Submitted: April 03, 2021 AEST, Accepted: May 25, 2021 AEST

This is an open-access article distributed under the terms of the Creative Commons Attribution 4.0 International License (CCBY-SA-4.0). View this license's legal deed at https://creativecommons.org/ licenses/by-sa/4.0 and legal code at https://creativecommons.org/licenses/by-sa/4.0/legalcode for more information. 


\section{REFERENCES}

Biggs, J. 2019. “Welcome to the FactorAnalyzer Documentation!” 2019. https://factoranalyzer.readthedocs.io/en/latest/index.html.

Chauhan, R. S., D. Capasso da Silva, D. Salon, A. Shamshiripour, E. Rahimi, U. Sutradhar, S. Khoeini, A. Mohammadian, S. Derrible, and R. M. Pendyala. 2021. "COVID-19 Related Attitudesand Risk Perceptions across Urban, Rural, and Suburban Areas in the United States."

Chauhan, R. S., M. W. Conway, D. Capasso da Silva, D. Salon, A. Shamshiripour, E. Rahimi, and R. M. Pendyala. 2021. "A Database of Travel-Related Behaviors and Attitudes Before, During, and After COVID-19 in the United States.”

Conway, Matthew W., Deborah Salon, Denise Capasso da Silva, and Laura Mirtich. 2020. "How Will the COVID-19 Pandemic Affect the Future of Urban Life? Early Evidence from HighlyEducated Respondents in the United States." Urban Science 4 (4): 50. https://doi.org/10.3390/ urbansci4040050.

Kroesen, M., S. L. Handy, and C. Chorus. 2017. "Do Attitudes Cause Behavior or Vice Versa? An Alternative Conceptualization of the Attitude-Behavior Relationship in Travel Behavior Modeling." Transportation Research Part A 101: 190-202. https://doi.org/10.1016/ j.tra.2017.05.013.

Salon, Deborah, Matthew Wigginton Conway, Denise Capasso Da Silva, Rishabh Chauhan, Ali Shamshiripour, Ehsan Rahimi, Laura Mirtich, et al. 2021. "COVID Future Wave 1 Survey Data v1.0.0.” ASU Library Research Data Repository. https://doi.org/10.48349/ASU/QO7BTC.

United States Census Bureau. 2021. "Poverty Thresholds.” 2021. https://www.census.gov/data/ tables/time-series/demo/income-poverty/historical-poverty-thresholds.html. 


\section{Appendix}

\begin{tabular}{|c|c|c|c|c|c|}
\hline \multicolumn{2}{|c|}{$\begin{array}{l}\text { Standard Error }=\text { sqrt }[\mathrm{p}(1-\mathrm{p}) / \mathrm{n}) \\
\text { where } \\
\mathrm{p} \text { is the weighted sample proportion, and } \\
\mathrm{n} \text { is the weighted sample size. }\end{array}$} & $\begin{array}{l}\text { Primarily } \\
\text { concerned } \\
\text { about health }\end{array}$ & $\begin{array}{c}\text { Equally } \\
\text { concerned } \\
\text { about health } \\
\text { and the } \\
\text { response } \\
\end{array}$ & $\begin{array}{c}\text { Least } \\
\text { concerned } \\
\text { about health } \\
\text { and about } \\
\text { the response }\end{array}$ & $\begin{array}{c}\text { Primarily } \\
\text { concerned } \\
\text { about the } \\
\text { response }\end{array}$ \\
\hline & Weighted sample: & 2884 & 2014 & 1599 & 1092 \\
\hline \multirow[t]{4}{*}{ Age } & 18-29 years & $0.7 \%$ & $0.9 \%$ & $1.1 \%$ & $1.2 \%$ \\
\hline & $30-44$ years & $0.8 \%$ & $1.0 \%$ & $1.1 \%$ & $1.4 \%$ \\
\hline & $45-59$ years & $0.8 \%$ & $1.0 \%$ & $1.0 \%$ & $1.4 \%$ \\
\hline & $60+$ years & $0.9 \%$ & $1.0 \%$ & $1.1 \%$ & $1.3 \%$ \\
\hline \multirow[t]{2}{*}{ Gender } & Female & $0.9 \%$ & $1.1 \%$ & $1.2 \%$ & $1.5 \%$ \\
\hline & Male & $0.9 \%$ & $1.1 \%$ & $1.2 \%$ & $1.5 \%$ \\
\hline \multirow[t]{3}{*}{ Education } & High school or less & $0.9 \%$ & $1.1 \%$ & $1.2 \%$ & $1.5 \%$ \\
\hline & Some college & $0.9 \%$ & $1.0 \%$ & $1.1 \%$ & $1.4 \%$ \\
\hline & Bachelor or higher & $0.9 \%$ & $1.0 \%$ & $1.1 \%$ & $1.3 \%$ \\
\hline \multirow{6}{*}{$\begin{array}{l}\text { Annual household } \\
\text { income in 2019* (i.e., } \\
\text { pre-pandemic income) }\end{array}$} & Less than $\$ 35,000$ & $0.7 \%$ & $0.9 \%$ & $1.1 \%$ & $1.2 \%$ \\
\hline & $\$ 35,000$ to $\$ 49,999$ & $0.6 \%$ & $0.8 \%$ & $0.8 \%$ & $0.9 \%$ \\
\hline & $\$ 50,000$ to $\$ 74,999$ & $0.7 \%$ & $0.8 \%$ & $0.9 \%$ & $1.2 \%$ \\
\hline & $\$ 75,000$ to $\$ 99,999$ & $0.6 \%$ & $0.7 \%$ & $0.8 \%$ & $1.1 \%$ \\
\hline & $\$ 100,000$ to $\$ 124,999$ & $0.6 \%$ & $0.7 \%$ & $0.9 \%$ & $1.1 \%$ \\
\hline & $\$ 125,000$ or more & $0.8 \%$ & $1.0 \%$ & $1.0 \%$ & $1.3 \%$ \\
\hline \multirow[t]{5}{*}{ Household vehicles } & 0 & $0.5 \%$ & $0.6 \%$ & $0.9 \%$ & $0.7 \%$ \\
\hline & 1 & $0.8 \%$ & $1.0 \%$ & $1.1 \%$ & $1.2 \%$ \\
\hline & 2 & $0.9 \%$ & $1.1 \%$ & $1.2 \%$ & $1.5 \%$ \\
\hline & 3 & $0.8 \%$ & $0.9 \%$ & $1.0 \%$ & $1.3 \%$ \\
\hline & 4 or more & $0.5 \%$ & $0.7 \%$ & $0.6 \%$ & $1.0 \%$ \\
\hline Presence of children & Present & $0.9 \%$ & $1.1 \%$ & $1.2 \%$ & $1.5 \%$ \\
\hline \multirow{5}{*}{$\begin{array}{l}\text { Attitudes (Percent of } \\
\text { those who agree or } \\
\text { strongly agree with } \\
\text { statement) }\end{array}$} & $\begin{array}{l}\text { Learning how to use new } \\
\text { technologies is often frustrating to me } \\
\text { I am committed to using less }\end{array}$ & $0.9 \%$ & $1.1 \%$ & $1.1 \%$ & $1.4 \%$ \\
\hline & $\begin{array}{l}\text { polluting means of transportation as } \\
\text { much as possible }\end{array}$ & $0.9 \%$ & $1.1 \%$ & $1.2 \%$ & $1.3 \%$ \\
\hline & $\begin{array}{l}\text { Even if I do not end up buying } \\
\text { anything, I still enjoy going to } \\
\text { stores and browsing }\end{array}$ & $0.9 \%$ & $1.1 \%$ & $1.2 \%$ & $1.5 \%$ \\
\hline & $\begin{array}{l}\text { Having shops and services within } \\
\text { walking distance of my home is } \\
\text { important to me }\end{array}$ & $0.9 \%$ & $1.1 \%$ & $1.2 \%$ & $1.5 \%$ \\
\hline & I dislike change & $0.9 \%$ & $1.1 \%$ & $1.2 \%$ & $1.5 \%$ \\
\hline
\end{tabular}

Table 4. Standard Errors Associated with the Proportions Shown in Table 1 
Standard Error $=\operatorname{sqrt}[\mathrm{p}(1-\mathrm{p}) / \mathrm{n})$ where

$\mathrm{p}$ is the weighted sample proportion, and $\mathrm{n}$ is the weighted sample size.

\begin{tabular}{|c|c|c|c|c|c|c|}
\hline \multicolumn{3}{|c|}{ Weighted sample: } & 2884 & 2014 & 1599 & 1092 \\
\hline Restaurant Patronage & \multicolumn{2}{|c|}{$\mathbf{0}$} & $0.7 \%$ & $1.1 \%$ & $1.1 \%$ & $1.5 \%$ \\
\hline Number of days dining & \multicolumn{2}{|l|}{1} & $0.6 \%$ & $0.9 \%$ & $1.0 \%$ & $1.4 \%$ \\
\hline out in the past week & \multicolumn{2}{|l|}{$2-3$} & $0.4 \%$ & $0.7 \%$ & $0.8 \%$ & $1.1 \%$ \\
\hline & \multicolumn{2}{|l|}{4 or more } & $0.2 \%$ & $0.4 \%$ & $0.2 \%$ & $0.4 \%$ \\
\hline In-person Grocery & \multicolumn{2}{|l|}{$\mathbf{0}$} & $0.8 \%$ & $0.8 \%$ & $0.9 \%$ & $1.0 \%$ \\
\hline Shopping Number of & \multicolumn{2}{|l|}{1} & $0.9 \%$ & $1.1 \%$ & $1.2 \%$ & $1.5 \%$ \\
\hline days grocery shopping & \multicolumn{2}{|l|}{ 2-3 } & $0.8 \%$ & $1.0 \%$ & $1.2 \%$ & $1.5 \%$ \\
\hline in the past week & \multicolumn{2}{|l|}{4 or more } & $0.3 \%$ & $0.6 \%$ & $0.5 \%$ & $0.8 \%$ \\
\hline Online Shopping & \multicolumn{2}{|l|}{0} & $0.9 \%$ & $1.1 \%$ & $1.2 \%$ & $1.5 \%$ \\
\hline Number of days & \multicolumn{2}{|l|}{1} & $0.8 \%$ & $1.0 \%$ & $1.1 \%$ & $1.4 \%$ \\
\hline ordering non-grocery & \multicolumn{2}{|l|}{$2-3$} & $0.9 \%$ & $1.0 \%$ & $1.1 \%$ & $1.2 \%$ \\
\hline items in the past week & \multicolumn{2}{|l|}{4 or more } & $0.5 \%$ & $0.6 \%$ & $0.6 \%$ & $0.7 \%$ \\
\hline \multirow[b]{2}{*}{$\begin{array}{c}\text { Work from Home } \\
\text { (Workers who had the } \\
\text { choice to work from } \\
\text { home) }\end{array}$} & \multicolumn{2}{|c|}{ Weighted sample size } & 780 & 614 & 430 & 261 \\
\hline & \multicolumn{2}{|c|}{$\begin{array}{c}\text { Percent Working Entirely } \\
\text { Remote in Past } 7 \text { Days } \\
\text { (zero trips to work, worked from } \\
\text { home } 5+\text { days) }\end{array}$} & $1.8 \%$ & $1.8 \%$ & $2.4 \%$ & $3.1 \%$ \\
\hline \multirow{7}{*}{$\begin{array}{l}\text { Daily travel } \\
\text { (Based on the number } \\
\text { of days mode was used } \\
\text { in the 7-day period } \\
\text { prior to the survey) }\end{array}$} & Private vehicle $N u m b e r$ & $0-1$ & $0.8 \%$ & $0.9 \%$ & $1.1 \%$ & $1.0 \%$ \\
\hline & of days using the mode in & $2-3$ & $0.8 \%$ & $1.0 \%$ & $1.0 \%$ & $1.0 \%$ \\
\hline & the past week $\left(\chi^{2}=376\right.$ & 4-6 & $0.8 \%$ & $1.0 \%$ & $1.1 \%$ & $1.3 \%$ \\
\hline & $p=0.000)$ & 7 & $0.8 \%$ & $1.0 \%$ & $1.1 \%$ & $1.5 \%$ \\
\hline & \multicolumn{2}{|c|}{$\begin{array}{c}\text { Transit use Share of respondents } \\
\text { who used the mode }\end{array}$} & $0.5 \%$ & $0.8 \%$ & $0.7 \%$ & $0.8 \%$ \\
\hline & \multicolumn{2}{|c|}{$\begin{array}{l}\text { Personal bike Share of } \\
\text { respondents who used the mode }\end{array}$} & $0.7 \%$ & $1.0 \%$ & $1.0 \%$ & $1.2 \%$ \\
\hline & \multicolumn{2}{|c|}{$\begin{array}{c}\text { Immobility Share of respondents } \\
\text { who did not travel at all }\end{array}$} & $0.4 \%$ & $0.4 \%$ & $0.4 \%$ & $0.4 \%$ \\
\hline
\end{tabular}

Table 5. Standard Errors Associated with the Proportions Shown in Table 2 